\title{
THE SUN-DANCE OF MELISSODES.
}

\author{
C. H. TURNER, AUgusta, GA.
}

THe time was the month of August; the place, an abandoned garden in Augusta, Georgia. In one end of that garden, where a poor stand of grass had supplanted the beans which once flourished there, a host of burrowing-bees, bearing the generic name Melissodes, had excavated their burrows. Some of these burrows were exposed in barren spots, while others were hidden, more or less, in clumps of grass. At any hour of the day, these industrious burrowing-bees could be seen storing their nests with pollen; while the euckoo-bees [Nomadid $x$ loitered on neighboring grass-blades or hovered about the burrows, waiting for an opportunity to lay their eggs upon the stored-up food of the industrions Melissodes. Crossing the path of the breeze and the rays of the sum at every possible angle, active alike in sunshine and shadow, yet disturbed by eren slight changes in the topographical environment of the burrow, the female Melissodes continues her work from early morn until set of sun; proclaiming, in deeds more eloquent than words: "My behavior is much more than a complex of anemotropisms and phototropisms, for my homing is controlled by memory pictures of the environment of my nest."

At one spot in this garden, a place where the sun shone brightly all the day long, there was a conspicuous pateh of grass about five feet long and two feet wide. In and about this grass-plot were situated, at irregular intervals, several burrows of this bee. Usually a burrow was the property of a single female; but in some cases two, and in yet rarer cases three, bees utilized the same burrow. A round trip to the pollen fields required only about trenty minutes. Since all the bees did not start for the forage grounds at the same time, hardly five minutes of daylight passed by without a female Melissodes passing near to or across that plot of ground. This patch of grass was the site of the dance of which this article treats. Although daily, for a whole week, several hours were deroted to a study of this dance, yet it was never performed at any other place in the garden.

Many a time have I watehed the wind-danee of the Diptera - watehed the flies, hovering several feet above the ground, with their heads all facing the wind, rise and fall in rhythmic morements. This sun-dance of Melissodes is not sueh a tropism, for the axis of the body bears no constant relation either to the direction of the wind or to the rays of the sun. Nor is it like any of the human square dances, where a constant number of people arrange themselves in ever shifting geometrical patterns; 
this dance of the bees seems to be a free for all performance. Usually several bees are engaged, but as few as one and as many as fifteen have been observed participating at the same time, and the plotting of the eurves in which they move would puzzle the brain of a skilled mathematician. Neither is it like the popular round dances, where each couple forms an independent unit; for although one bee often chases and sometimes embraces another, there are no permanent dual units. No more is it like a jig, where each individual is an independent unit; but, it is more like the game of cross-tag, of which so many children are fond. Arranged without any apparent system, and schlom rising more than a few inches above the tops of the grass stalks, the bees clart here and there in irregular lines. Moving in complex curves of short radii, (hasing each other, dodging one another, dropping into the grass, knocking each other down, clasping momentarily and rolling upon the ground, clarting off for several yards and then returning, at times resting for a moment upon a blacke of grass - such behavior, repeated over and over again, sometimes in one orter and sometimes in another, is the essence of the sun-dance of IVclissodes. No skilled musician plays entrancing tunes; but, as they dance, each bee makes music with its wings.

What is the meaning of all this? Were the participants of the dance young females, an explanation would be easy; for it would be considered an instinctive play the function of which is to furnish memory pictures of the environment in which they will excarate their nests. But they are not young females; their yellow clypei, flashing in the sun, prorlaim them males. Ever alert for the black clypei of the female, I bare scrutinized this dince for hours; but the regular participants always displayed yellow clypei, the badge of maleness. Participants captured in my insect net toll the same story. At regular intervals, females do appear, for a moment, in the midst of the dancers. These, howerer, are not young bees; the conspicuous loads of golden pollen, which burden the dense scopa of their hind legs, proclaim them mature females that are hurying homeward with foot for their oflispring. On the appearance of such a female, a male usually darts after her. Often several do so simultaneously. The alert female usually dodges them and contimues homeward. The males may even follow her to the burrow, and, hovering about until she reappears, give chase. Sometimes the female's dodging is ineffective and she is struck by the head of the chasing male. In such cases she is knocked to the ground. Although, as a rule, the male drops immediately to the ground, yet the female usually escapes to her burrow. In yet other cases the pursuing male succeeds in seeuring a more or less hold upon the female. They both then fall to the ground and roll orer and orer. Eren then the female frequently dislodges the male and escapes to her bur- 
row; but, occasionally after a short roll upon the grount, the female walks leisurely along, bearing upon her back, in coition, the victorious male. Alter a lapse of a few minutes, the female returns to her burrow and the male to his dance. 'This is the significance of the sun-dance of Melissorles; perhaps it were better to call it a nuytial ambuscade, since it is a devire which promotes sexual mion.

Hanes Norual Serhool, sipt. 15,1908 .

'The title page and index for Volume XT of Psyche will be mailed with the next number. 

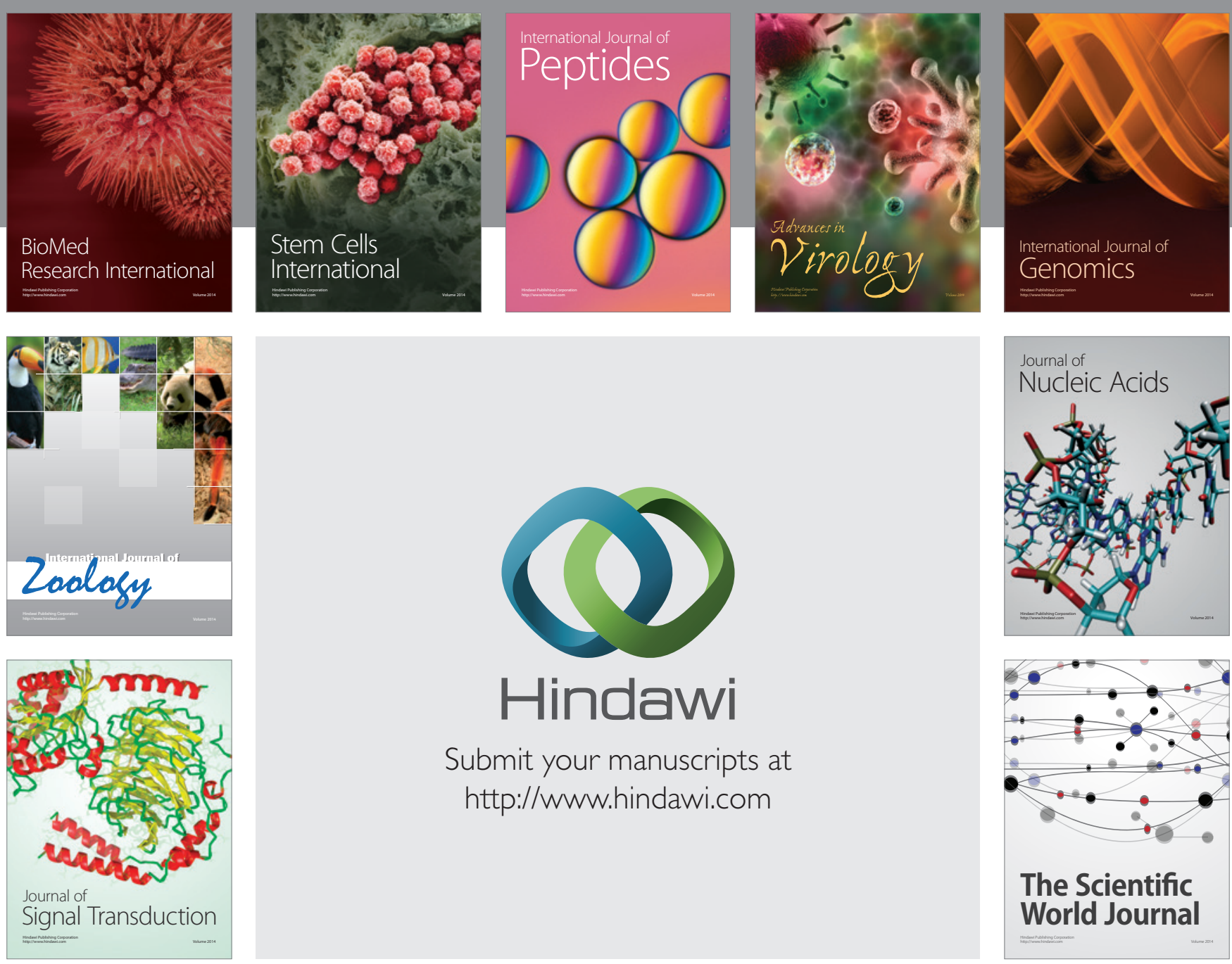

Submit your manuscripts at

http://www.hindawi.com
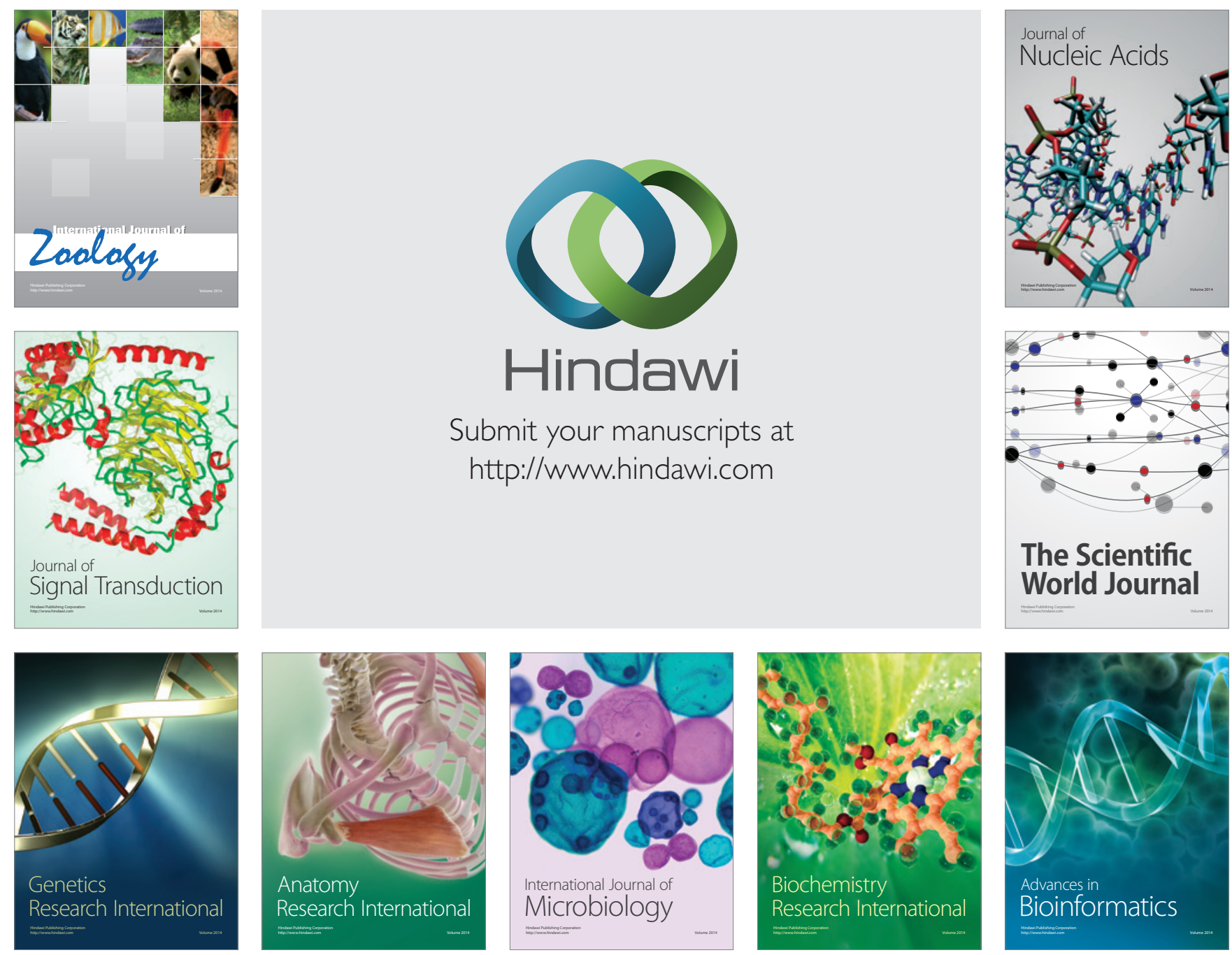

The Scientific World Journal
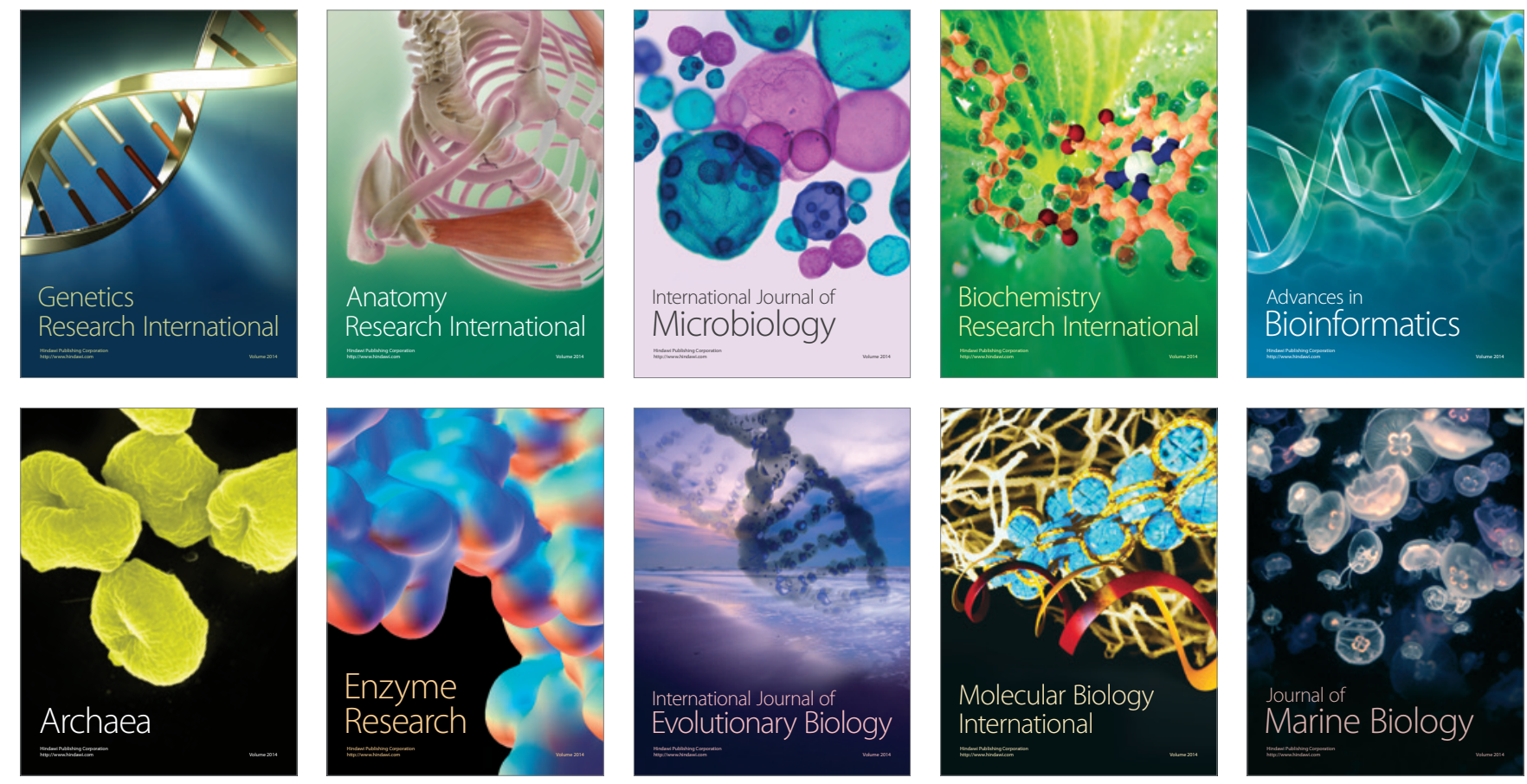